\title{
6.2. Eklektyzm ideologiczny partii politycznych, czyli profil ideologiczny w praktyce - Anita Filipczak-Biatkowska
}

https://doi.org/10.18778/8220-429-2.13

\subsubsection{Cele referowanego badania}

Diagnoza stanu zróżnicowania ideologicznego polskiego dyskursu parlamentarnego w latach 2005-2006 to główny cel badania, które referuję w tym rozdziale. Inspiracją do podjęcia rozważań na temat tego zagadnienia były zadane sobie pytania: czy w Polsce na pewno zachowana jest demokracja? Skąd to wiadomo i kto to weryfikuje? Pewnych założeń w tym obszarze dostarcza Konstytucja Rzeczpospolitej Polskiej, w której stwierdza się, że Polska jest (a przynajmniej powinna być) krajem demokratycznym. Skoro tak, jedną z głównych zasad funkcjonowania państwa powinien być pluralizm polityczny przejawiający się $\mathrm{w}$ parlamentarnym systemie partyjnym. Pluralizm polityczny polega na istnieniu dwóch lub więcej partii politycznych, reprezentujących różne programy i orientacje polityczne, walczących na równych prawach o zdobycie władzy w państwie. Struktura polskiej sceny politycznej zdaje się potwierdzać jej ideologiczną dyferencjację - w każdej kadencji sejmu w parlamencie funkcjonuje kilka ugrupowań, często deklarujących się jako opozycyjne względem innych. Jednocześnie zawarte $\mathrm{w}$ definicji pluralizmu politycznego stwierdzenie, że programy partii powinny różnić się między sobą, jest dość ogólne, a tym samym bardzo trudno poddać je weryfikacji - jak bowiem stwierdzić, czy partie rzeczywiście reprezentują różne orientacje polityczne? W świetle przepisów prawa kryterium wystarczającym do zachowania pluralizmu politycznego jest funkcjonowanie w systemie partyjnym kilku partii (co najmniej dwu).

Podjęłam próbę ustalenia, czy istnieje różnorodność ideologiczna w polskim dyskursie parlamentarnym. Opieranie się na wspomnianych powyżej zapisach zawartych w programach wyborczych rodzi moim zdaniem istotne ograniczenia - nie od dziś wiadomo, że program polityczny partii pisany jest w określonym celu: ma przekonać potencjalnych wyborców do oddania głosu akurat na tę partię. Co więcej, często tworzony jest przez wąski zespól, który wyznacza drogę, jaką mają podążać pozostali członkowie partii. Jest wizytówką partii, tworzy jej oficjalny wizerunek. W związku z tym uznałam, że zbadanie wypowiedzi grupy posłów należących do pewnego ugrupowania i odtworzenie na tej podstawie poglądów politycznych tej partii będzie odznaczało się znacznie wyższym poziomem trafności niż charakterystyka poglądów partii z wykorzystaniem deklaracji zawartych w jej programie.

Przyjęłam hipotezę główną, która brzmiała:

H1: Wypowiedzi reprezentantów partii politycznych wskazują na pluralistyczny charakter polskiego systemu partyjnego. 
Obok niej weryfikacji poddałam również inne hipotezy - założyłam, że:

$\mathrm{H} 2$ : Profil ideologiczny partii zbudowany jest z komponentów różnych prototypowych systemów ideologicznych.

H3: W orientacji ideologicznej partii można wyznaczyć dominujący obszar ideologiczny, czyli pewne aspekty ideologiczne będą szczególnie licznie reprezentowane.

Wyznaczone cele badawcze sprawiły, że mój obszar badawczy umiejscowił się na styku badań z zakresu językoznawstwa i nauk o polityce. Pozostawało znaleźć odpowiednią metodę badawczą.

Język polityki nieustannie zajmuje ważne miejsce w obrębie zainteresowań badaczy, należy jednak podkreślić, że zmienił się sposób oglądu zjawisk językowych występujących w przestrzeni politycznej. Obecnie silny nurt badań w tym obszarze stanowią opracowania mieszczące się w ramach analizy dyskursu, która sytuuje się na szeroko pojętych peryferiach językoznawstwa i nauk społecznych. Założenia przyjęte $\mathrm{w}$ niniejszym badaniu, odnoszące się do sposobu analizy warstwy językowej tekstów, wskazują, że mieści się ono w paradygmacie analizy dyskursu, wybrany przedmiot badawczy sytuuje je zaś w pobliżu jej krytycznej odmiany. Między analizą dyskursu jako taką i jej krytycznym odłamem, czyli $\mathrm{KAD}$ (krytyczna analiza dyskursu) nie ma ostrej granicy. Wyróżnikiem KAD jest koncentracja na kwestiach społecznych i politycznych. Będąca przedmiotem tego badania ideologia, a konkretnie sposób jej przejawiania się w dyskursie partii politycznych w okresie IV RP, pozwala dostrzec związki z KAD - ideologia jest tu postrzegana jako determinanta działań podejmowanych przez jednostki w procesie kształtowania instytucji społecznych.

Badania zjawisk z obszaru społeczno-politycznego prowadzone stricte metodami analizy dyskursu lub pokrewnymi już od wielu lat cieszą się dużą popularnością, z powodu dużej liczby opracowań ich precyzyjne omówienie jest w tym miejscu niemożliwe. Aby jednak choć pokrótce scharakteryzować główne trendy tematyczne, należy powiedzieć, że w zakresie analiz językoznawczych pojawiały się prace opisujące specyfikę dyskursu w różnych mediach (m.in. Wasilewski, Skibiński 2008; Szkudlarek-Śmiechowicz 2010; Pałuszyńska 2012; Michalewski 2013; Wasilewski 2014; Grzegorzewski 2014; Loewe 2018), podejmowane były też dążenia do uchwycenia cech charakterystycznych różnicujących pododmiany języka polityki, demaskujące właściwe mu mechanizmy - przeglądu prac z tego zakresu dokonała Bożena Sieradzka-Baziur (2011), liczni badacze poświęcili tym problemom obszerne publikacje (m.in. Kamińska-Szmaj 2001; Kampka 2009). Sam dyskurs parlamentarny także zwrócił uwagę przedstawicieli świata nauki (m.in. Laskowska 2004; Siewierska-Chmaj 2004; Śpiewak 2004; Figiel 2009; Polkowska 2015; Charciarek 2015). W naukach społecznych badania prowadzone w paradygmacie analizy dyskursu skupione są na rozważaniach dotyczących tematów wywierających szczególny wpływ na postać debaty publicznej, co czyni te opracowania bardzo interesującymi poznawczo, z drugiej strony jednak 
na ich gruncie dostrzeżono niedostatki metod wykorzystywania danych językowych: „W naukach społecznych sekwencje tekstowe stosuje się zwykle jako ilustracje, zdania są wyjmowane z kontekstu, a konkretne sekwencje tekstowe są wykorzystywane do uzasadniania lub obalania twierdzeń, bez odnoszenia ich do całego materiału tekstowego i bez żadnego wyraźnego uzasadnienia czy dowodów zewnętrznych, uzasadniających taki, a nie inny wybór" (Wodak 2011: 11). Analiza dyskursu (zwłaszcza krytyczna analiza dyskursu) pozwala przezwyciężyć te niekorzystne czynniki. Jak wskazuje Ruth Wodak, obecnie obserwuje się w naukach społecznych (m.in. socjologii, antropologii, historii) „zwrot lingwistyczny” i „zwrot kulturowy”: wielu przedstawicieli tych dyscyplin „zauważa złożoność materiałów tekstowych i poszukuje bardziej adekwatnych metodologii ich analizy. Zwracają się oni ku analizie dyskursu w poszukiwaniu informacji i wsparcia merytorycznego" (2011: 12) (o filozoficznych podstawach zwrotu lingwistycznego zob. Rasiński 2009). Podsumowując przegląd badań mieszczących się w domenie analizy dyskursu, można stwierdzić, że opracowania opierające się na rzetelnych analizach językowych nie podejmują prób diagnozy zjawisk społeczno-politycznych, rozważania badaczy z obszaru nauk społecznych zaś opierają się na wybiórczo potraktowanym materiale językowym.

Referowane w tym rozdziale badanie opiera się na gruntownej i systematycznej analizie warstwy językowej zbioru tekstów politycznych (debat parlamentarnych) i prowadzi do wniosków, które pozwalają odtworzyć dyskurs ideologiczny wpływający na organizację przestrzeni społeczno-politycznego funkcjonowania państwa w badanym okresie. Parlament jest bowiem tym miejscem, w którym przyjmowane są zasadnicze dla funkcjonowania państwa ustawy. W krytycznej analizie dyskursu przyjmuje się, że ideologie decydują o ostatecznym kształcie i zasadach panujących $w$ różnych przestrzeniach społecznych. Ich badanie jest natomiast możliwe na mocy założenia, że ideologie (rozumiane jako reprezentacje kognitywno-spoleczne) ujawniają się poprzez język (por. Piekot, Poprawa 2009: 8), sam język zaś jest jednym z podstawowych narzędzi, jakim operuje się w obszarze działań politycznych.

Konsekwencją przyjętego za Elżbietą Laskowską założenia, że „parlament jest najbardziej typowym miejscem dla działań politycznych” (2004: 16) był wybór materiału badawczego, który stanowily wypowiedzi (teksty) polityków wygłaszane podczas debat parlamentarnych. Pozyskane zostały one ze strony Sejmu Rzeczpospolitej Polskiej, na której stenogramy posiedzeń dostępne są w postaci plików w formacie pdf. W pliku zawarta jest treść całego posiedzenia, jakie odbywa się określonego dnia obrad i obejmuje zazwyczaj kilka punktów w porządku dziennym. Debatę rozumiem jako działanie komunikacyjne mające na celu wybór najlepszego rozwiązania omawianego problemu lub sprawy (por. Pstrąg 2004), w związku z czym w opracowaniu przyjęlam, że debata parlamentarna odpowiada jednemu punktowi w porządku dziennym obrad Sejmu RP. Analizie poddałam 20 debat z 9 posiedzeń sejmowych. Materiał badawczy obejmuje okres od 23.11.2005 do 5.12.2006. 
W kompletowaniu materiału badawczego kierowałam się częściowo doborem losowym, częściowo przyjętym kluczem. Szerszego opisu i pewnych wyjaśnień wymaga dobór z klucza. Stosowałam tu kryterium ilościowe i jakościowe. Kryterium ilościowe przejawiało się w kontrolowaniu zawartości debat pod kątem liczby reprezentantów klubów parlamentarnych - preferowałam debaty, w których głos zabierali przedstawiciele wszystkich klubów parlamentarnych, a także takie, w których ich wypowiedzi byly stosunkowo długie, co uznawałam za syndrom wieloaspektowego ustosunkowania się do przedmiotu debaty. Pod względem kryterium jakościowego wybrałam do analizy debaty, których przedmiot był szczególnie ważny dla badanego okresu (dokonanie takiej oceny było możliwe, ponieważ badanie miało charakter diachroniczny - prowadzone było kilka lat później w stosunku do analizowanych wydarzeń). Założyłam, że tematy, które wywołały szeroką dyskusję także poza parlamentem, będą cechować się silnym zderzeniem konkurencyjnych poglądów w trakcie debaty parlamentarnej. W efekcie zastosowania przeze mnie tego kryterium, do materiału badawczego trafily m.in. debaty nad projektem ustawy o powołaniu Centralnego Biura Antykorupcyjnego, nad projektem ustawy o świadczeniach rodzinnych - spór o tzw. becikowe, nad projektem ustawy o zmianie Konstytucji Rzeczpospolitej Polskiej przez dopisanie słów „od momentu poczęcia” w art. 38, także debaty nad projektem uchwały w sprawie upamiętnienia 24 . rocznicy wprowadzenia stanu wojennego.

W każdej debacie parlamentarnej z badanego okresu prezentowanych było od 6 do 7 stanowisk partyjnych i stanowiska posłów niezależnych. W analizie uwzględniłam stanowiska następujących partii tworzących kluby parlamentarne: Prawo i Sprawiedliwość, Platforma Obywatelska, Sojusz Lewicy Demokratycznej, Samoobrona Rzeczypospolitej Polskiej, Liga Polskich Rodzin, Polskie Stronnictwo Ludowe. Stanowiska posłów niezależnych pominęłam.

Należy podkreślić, że uzyskane w badaniu wyniki obowiązują dla dyskursu parlamentarnego z okresu 2005-2006, określają, jaką orientację ideologiczną zamanifestowano wówczas w wypowiedziach wygłoszonych w sejmie. Ograniczenie to jest konsekwencją przyjętego założenia o fluktuacji poglądów w obrębie orientacji ideologicznej - uznaję, że orientacja ideologiczna ma charakter reaktywny, jest dynamiczna i zmienna, ponieważ jest zależna od aktualiów politycznych (por. Awdiejew 2008: 68). Rozszerzanie wyników na szerszy okres jest zatem nieuprawnione i może prowadzić do pojawiania się artefaktów badawczych.

\subsubsection{Schemat badania i czynności przygotowawcze}

Przyjęty w badaniu schemat postępowania badawczego (zwłaszcza dążenie do zminimalizowania wpływu badacza na uzyskane wyniki) wymagał zaszyfrowania tekstów, czyli dokonania ich anonimizacji. Analiza tekstów przebiegała zgodnie ze schematem przedstawionym w tabeli 1. 
Tabela 1. Schemat badania

\begin{tabular}{|c|c|c|c|c|c|}
\hline & Cel & $\begin{array}{c}\text { Podstawa } \\
\text { opracowania }\end{array}$ & & Procedura & Efekt \\
\hline \multirow{3}{*}{ 胥 } & \multirow[t]{3}{*}{$\begin{array}{l}\text { kodowanie } \\
\text { danych } \\
\text { językowych }\end{array}$} & \multirow[t]{3}{*}{$\begin{array}{l}\text { teksty } \\
\text { wypowiedzi } \\
\text { politycznych }\end{array}$} & 1 & $\begin{array}{l}\text { oddzielenie ramy } \\
\text { perswazyjnej od } \\
\text { tekstu właściwego }\end{array}$ & \multirow[t]{3}{*}{$\begin{array}{l}\text { baza sądów } \\
\text { ideologicznych }\end{array}$} \\
\hline & & & 2 & $\begin{array}{l}\text { analiza } \\
\text { paradygmatyczna }\end{array}$ & \\
\hline & & & 3 & $\begin{array}{l}\text { analiza } \\
\text { syntagmatyczna }\end{array}$ & \\
\hline \multirow{3}{*}{ 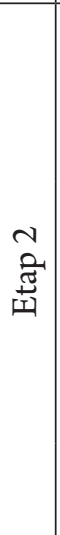 } & \multirow[t]{3}{*}{$\begin{array}{l}\text { ustalenie } \\
\text { orientacji } \\
\text { ideologicznej }\end{array}$} & \multirow[t]{3}{*}{$\begin{array}{l}\text { baza sądów } \\
\text { ideologicznych }\end{array}$} & 1 & $\begin{array}{l}\text { wyodrębnienie } \\
\text { znaczników ide- } \\
\text { ologicznych dla } \\
\text { badanych ideologii }\end{array}$ & \multirow[t]{3}{*}{$\begin{array}{l}\text { profil ideologiczny } \\
\text { wyrażony tabela- } \\
\text { rycznie (ewentual- } \\
\text { nie także graficznie) }\end{array}$} \\
\hline & & & 2 & $\begin{array}{l}\text { klasyfikowanie } \\
\text { uogólnionych } \\
\text { sądów ideologicz- } \\
\text { nych do odpowied- } \\
\text { nich znaczników } \\
\text { ideologicznych }\end{array}$ & \\
\hline & & & 3 & $\begin{array}{l}\text { utworzenie profilu } \\
\text { ideologicznego }\end{array}$ & \\
\hline
\end{tabular}

Źródło: opracowanie własne.

Ramę wypowiedzi perswazyjnej tworzą pomocnicze działania werbalne nadawcy, dążące do wykreowania wizerunku nadawcy, odbiorcy, związku i zaufania między nimi (zob. Awdiejew, Habrajska 2009: 26-28). Substrategie wspomagające, tworzące ramę perswazyjną, nie wiążą się na zasadzie wynikania z merytoryczną częścią wypowiedzi. Kreowanie wizerunku nadawcy ma służyć przede wszystkim wyeksponowaniu wiarygodności mówcy; aby ten efekt osiągnąć, politycy w badanych debatach parlamentarnych zwracali uwagę publiczności na fakt pozostawania w pobliżu dyskutowanych wydarzeń (związek ten mógł wynikać z właściwości życiorysu mówcy, pełnionych wcześniej funkcji publicznych itp.) bądź podkreślali, że dołożyli specjalnych starań, by zdobyć wiedzę na poruszany w wypowiedzi temat. Kreowanie wizerunku odbiorcy to substrategia, w której nadawca stara się dowartościować adresata swojej wypowiedzi, zaznaczając jego szczególne znaczenie dla sprawy lub dla samego nadawcy. Gdy mówcy chcieli wpłynąć na pozostałych parlamentarzystów, odwoływali się do ich inteligencji, kompetencji lub zdolności zrozumienia intencji nadawcy wypowiedzi, kiedy zaś planowany wplyw zorientowany był na obywateli oglądających debatę za pośred- 
nictwem mediów, wówczas strategia bywała bardziej rozbudowana: „wykazanie się znajomością warunków życia określonej grupy spolecznej, faktów z życia określonej osoby jest swoistym komplementem dla niej, potwierdzeniem, że pozostaje ona w sferze zainteresowań i troski danego polityka" (Filipczak-Białkowska 2018: 79).

Fragmenty badanych tekstów należące do ramy perswazyjnej należało wyeliminować z dalszej części prac analitycznych.

\subsubsection{Analiza właściwa}

Sposób analizy właściwego tekstu - zgodnie z założeniami przyjętymi w gramatyce komunikacyjnej - przebiegał na dwóch płaszczyznach: paradygmatycznej i syntagmatycznej:

Na płaszczyźnie paradygmatycznej analizowane są typy danego kroku strategicznego oraz zastosowanych $\mathrm{w}$ nim środków perswazyjnych. Z kolei na płaszczyźnie syntagmatycznej analizuje się relacje pomiędzy cząstkowymi konkluzjami poszczególnych kroków strategicznych oraz ich stosunek do ogólnego celu propagandowego, do którego dany dyskurs dąży. Konkluzje kroków strategicznych mogą tworzyć różne konfiguracje w syntagmatyce dyskursu propagandowego (Awdiejew, Habrajska 2009: 31).

Analiza paradygmatyczna polega na badaniu emotywno-oceniających aktów mowy, dotarcie do sądów ideologicznych w przyjętej metodzie wymaga bowiem analizy aktów mowy, które niosą informację na temat sposobu oceny przedstawianego stanu rzeczy. Typowe akty mowy emotywno-oceniające wprowadzane są odpowiednimi operatorami, istnieją także akty mowy, w których funkcja oceniająca występuje jako towarzysząca (o funkcjonowaniu aktów mowy emotywno-oceniających w dyskursie parlamentarnym zob. Laskowska 2004; Filipczak 2010). Akty mowy emotywno-oceniające w badanym dyskursie parlamentarnym wprowadzane były w następujący sposób (przedstawione poniżej mechanizmy językowe opatrzone są przykładami pochodzącymi ze scharakteryzowanego powyżej materiału badawczego):

- bezpośrednia formula opisowa wyrażająca stan emocjonalny, np. „Przeraża mnie myśl o tych wszystkich, którzy zabijają własne sumienia, aby móc dokonać aborcji”, „Chcę powiedzieć, że duma napawa mnie fakt działalności w Niezależnym Zrzeszeniu Studentów”, „Ale niepokoi mnie i boli, że wielu parlamentarzystów Prawa i Sprawiedliwości, występując w niektórych mediach, prezentuje zupełnie inne stanowisko [nie zgadzają się z potrzebą wprowadzenia do Konstytucji słów „od momentu poczęcia” - AFB]”;

- użycie tzw. leksemu nacechowanego (operatora syntetycznego) lub idiomu w strukturze wypowiedzenia oceniającego zachowanie się odbiorcy, 
np. „Zmorą naszych dróg są poruszający się od zmierzchu do świtu rowerzyści niewidzialni dla innych uczestników ruchu drogowego”, „Ta bezkarność pijanych kierowców, powiem: pijanych morderców, powoduje, że na polskich drogach ginie coraz więcej osób”, „Po trzecie, przecież otrzymywanie świadczenia w wyniku uznania, że dziecko zostało poczęte na skutek czynu zabronionego, jest w każdym przypadku, w przypadku gwałtu, a także, a może zwłaszcza, w przypadku kazirodztwa, na pewno stygmatyzowaniem dziecka”, „A co do nowych miejsc pracy, to tyle, co kot napłakal”;

- zastosowanie operatora analitycznego, składniowo niezależnego leksemu, np. „Niestety, jesteśmy za biedni, przy tych poziomach długu i deficytu liczyć na siebie nie możemy [liczyć na polskie dochody, a nie na środki z UE - AFB]”, „W chwili obecnej w Polsce życie człowieka od chwili poczęcia chroni ustawa z 7 stycznia 1993 roku o planowaniu rodziny, ochronie płodu ludzkiego i warunkach dopuszczalności przerywania ciąży. Niestety ustawa ta dopuszcza trzy wyjątki bezkarnego pozbawienia życia poczętego dziecka”, „Na szczęście struktury europejskie, jeśli chodzi o ochronę życia poczętych dzieci, nie mogą nam w sensie formalnym nic narzucić”, „Dlatego trzeba wreszcie postawić tamę powracającym sporom o to, czy należy uznawać prawo do życia tylko wybranej grupy, czy wszystkich ludzi niezależnie od wieku”;

- użycie frazemu jako operatora emotywnego, np. „To jest bardzo ważne, że wreszcie dostrzeżono, iż właścicielem czegoś może być także samorząd, a nie tylko państwo”, „Dlatego dobrze by było, panie ministrze, aby w przyszłorocznym budżecie znaleźć większe środki na wsparcie tych dwóch działań, czyli uprawy roślin energetycznych i rejestracji produktów tzw. regionalnych, tak aby wszyscy, którzy będą chcieli z tego zadania skorzystać, mogli takie wsparcie uzyskać”, „Czy rzeczywiście ochrona życia, za czym jesteśmy, wymaga takiej regulacji?”, „Nie mamy pewności, czy doktrynerska lewica za lat kilka, co nie daj Boże, nie dokona zamachu na prawną ochronę życia i nie wprowadzi nam aborcji na życzenie, zwłaszcza że to zapowiada nawet dzisiaj ustami jej przewodniczącego pana posła O.”;

- wyrażenie przekonania o powinności, np. „To jest bardzo często mienie i własność tych społeczności lokalnych i dlatego w razie prywatyzacji, sprzedaży części udziałów czy części przedsiębiorstwa powinny to być dochody samorządu”, „Panie premierze, mówil pan, i tu pana popieramy, że nie powinno to wsparcie [becikowe - AFB] dotyczyć tych, którzy mają bardzo wysokie wynagrodzenia”, „Panie premierze, dlaczego ustawą budżetową pozbawia pan przedsiębiorstwa wplywów z dywidendy - środki te w większości powinny służyć rozwojowi tych przedsiębiorstw - doprowadzając $w$ ten sposób do ich osłabienia, a nawet bankructwa poprzez wyeliminowanie z rynku przez konkurencyjne firmy?”, „Prawo do życia nie powinno być sytuowane na poziomie niższym niż inne, często bardziej względne prawa człowieka";

- zastosowanie sądu oceniającego wprowadzanego przez operatory polifunkcjonalne, np. „Oddajmy hołd, uczcijmy godnie ofiary stanu wojennego, ale nie piszmy swojej nowej, z pewnością obarczonej ciężarem własnych doświad- 
czeń, historii tamtego budzącego tak wiele emocji okresu”, „Dlatego, abstrahując już od omawianej ustawy, proponujemy, aby spółki Skarbu Państwa podzielić na strategiczne i niestrategiczne, żeby strategiczne dokapitalizować i żeby o powołaniu do rad nadzorczych decydowała m.in. opinia komisji skarbu, żeby pozbyć się kolesiostwa”, „Wiemy, że zapóźnienia są tam ogromne i wiemy, że żeby wykorzystać programy pomocowe Unii Europejskiej, musimy zabezpieczyć środki własne. O to do pana premiera apeluje".

Celem paradygmatycznej analizy było uzyskanie kolekcji sądów aksjologicznych wyeksponowanych przez nadawcę na powierzchni tekstu w postaci aktów mowy emotywno-oceniających. Ich obecność w tekście sygnalizowana jest przez zastosowane środki językowe, czyli operatory interakcyjne. Te sądy aksjologiczne należy wyodrębnić i zapisać w postaci samodzielnych zdań, np.

- „Wiemy, że zapóźnienia są tam ogromne i wiemy, że żeby wykorzystać programy pomocowe Unii Europejskiej, musimy zabezpieczyć środki własne. $\mathrm{O}$ to do pana premiera apeluję" $\rightarrow$ sąd aksjologiczny: Rząd powinien zabezpieczyć finanse na pokrycie wkładu ze środków własnych $\mathrm{w}$ procesie uzyskiwania pomocy z Unii Europejskiej;

- „Czy rzeczywiście ochrona życia, za czym jesteśmy, wymaga takiej regulacji?” $\rightarrow$ sąd aksjologiczny: Ludzkie życie powinno podlegać ochronie;

- „Oddajmy hołd, uczcijmy godnie ofiary stanu wojennego, ale nie piszmy swojej nowej, z pewnością obarczonej ciężarem własnych doświadczeń, historii tamtego budzącego tak wiele emocji okresu" $\rightarrow$ sądy aksjologiczne: Należy uczcić ofiary stanu wojennego; Nie należy zmieniać historii okresu stanu wojennego w Polsce.

Odtworzenie wyrażonych za pomocą aktów mowy emotywno-oceniających sądów aksjologicznych kończyło ten krok analityczny.

Analiza syntagmatyczna polega na standaryzacji ciągów argumentacyjnych zawartych w badanym tekście. Naturalnie skonstruowane wypowiedzi argumentacyjne, stosowane w rzeczywistych sytuacjach komunikacyjnych, zbudowane są na zasadzie entymematu - w ich werbalizacji pomija się jeden element argumentu (czasem dwa), zakładając, że jego odtworzenie nie stwarza odbiorcy kłopotu. Zazwyczaj samo zestawienie treści wypowiadanych słów z sytuacją komunikacyjną każe domyślać się intencji, jaką chce zrealizować nadawca, i doprecyzować zastosowany przez niego argument, czyli doprowadzić go do postaci wyrażonej w schemacie:

RO (reguła ogólna): Q $(X)$

SK (sąd kwalifikujący): $\mathrm{x} \in \mathrm{X}$

K (konkluzja): Q (x)

gdzie X oznacza klasę obiektów ideologicznych, $\mathrm{x}$ to konkretny obiekt rzeczywistości politycznej, a Q to określona atrybucja (por. Awdiejew 2008: 69). 
Przykład takiej analizy przedstawiam poniżej:

Z zadowoleniem przyjmujemy fakt znalezienia pieniędzy na dopłaty do paliwa rolniczego. Uważamy, że środki te pośrednio będa stużyć wzrostowi konkurencyjności polskich rolników $i$ ich produktów na rynku europejskim.

Emotywno-oceniający akt mowy wprowadzony został tutaj za pomocą bezpośredniej formuly opisowej „z zadowoleniem”, wyrażał on pozytywne nastawienie do tematu debaty, innymi słowy, zawierał sąd aksjologiczny, który można zwerbalizować w następujący sposób: „Rząd powinien zabezpieczyć środki na dopłaty do paliwa rolniczego”, i drugi: „Dopłaty do paliwa rolniczego są formą wsparcia konkurencyjności polskich rolników na rynku europejskim”. Zacytowany przykład to typowa wypowiedź argumentacyjna wyrażona w formie entymematu: nadawca nie zawarł w wypowiedzi reguły ogólnej, zakładając, że jej odtworzenie nie będzie stanowiło dla nadawcy większych trudności. Pierwsze zdanie w zacy towanej wy powiedzi jest wyrażeniem konkluzji, w której obiektowi konkretnemu „zapewnienie dopłat do paliwa rolniczego” przypisano wartość pozytywną poprzez zastosowanie operatora emotywno-oceniającego „z zadowoleniem” (jest to zatem akt mowy emotywno-oceniający wyrażający zadowolenie wprowadzony operatorem w postaci bezpośredniej formuly opisowej „z zadowoleniem”). Drugie zdanie w przytoczonym przykładzie wyraża sąd kwalifikujący. Odniesienie zidentyfikowanych elementów argumentu do jego struktury dało następujące wnioski cząstkowe: konkretny obiekt rzeczywistości (x) to „zapewnienie dopłat do paliwa rolniczego”, wartość, jaką przypisano (Q), wyraża się przez stwierdzenie powinności państwa w tym zakresie. W strukturze sądu kwalifikującego konkretny obiekt rzeczywistości (x) został zaszeregowany do klasy obiektów (X), którą w badanym argumencie stanowiło stosowanie form wspierania konkurencyjności polskich rolników na rynku europejskim. Zidentyfikowanie elementów cząstkowych pozwoliło zwerbalizować zastosowaną regułę ogólną: „Państwo powinno stosować formy wspierania konkurencyjności polskich rolników na rynku europejskim”. Cały argument prezentuje się następująco:

Reguła ogólna (RO): Państwo powinno stosować formy wspierania konkurencyjności polskich rolników na rynku europejskim.

Sąd kwalifikujący (SK): Dopłaty do paliwa rolniczego są formą wsparcia konkurencyjności polskich rolników na rynku europejskim.

Konkluzja (K): Państwo powinno zapewnić dopłaty do paliwa rolniczego.

Zidentyfikowana reguła ogólna wyraża uogólniony sąd ideologiczny, który treściowo odpowiada założeniom o protekcjonalności gospodarczej (typowej dla socjalizmu). 
W efekcie tego etapu badań na podstawie przeanalizowanego materiału powstały kolekcje uogólnionych sądów ideologicznych dla badanych partii politycznych. Sądy te uznałam za wyraz orientacji ideologicznej tych partii.

Opisane dwa etapy analizy - paradygmatyczna i syntagmatyczna - odnoszą się do działań badawczych na poziomie jednostkowych tekstów. Na ich podstawie uzyskałam wnioski na temat stosowanych mechanizmów językowych, efektem dodatkowym były także kolekcje - nieuporządkowanych jeszcze - sądów ideologicznych. Wyciągnięcie jakichkolwiek wniosków na podstawie tych kolekcji wymagało wyjścia z poziomu tekstu i przejścia na poziom dyskursu - spojrzenia na badany dyskurs w sposób globalny i odwołania się do planu interdyscyplinarnego.

\subsubsection{Kategoryzacja sądów ideologicznych}

Uogólnione sądy ideologiczne zwerbalizowane w wyniku przeprowadzenia analizy paradygmatycznej i syntagmatycznej należało posegregować, przyporządkowując je do wyodrębnionych znaczników ideologicznych. Podstawową zasadą była tutaj treściowa odpowiedniość obszaru ideologii wyrażonego określonym znacznikiem ideologicznym i sensu zawartego w uogólnionym sądzie ideologicznym. Wyniki tego działania analitycznego prezentuję w tabeli 2. Uporządkowane zostały w niej uogólnione sądy ideologiczne zidentyfikowane w wypowiedziach przedstawicieli partii Prawo i Sprawiedliwość. Z konieczności prezentuję tu tylko fragment - bazy sądów ideologicznych są obszerne, w referowanym badaniu wyodrębnionych zostało około 200 rekordów dla każdej partii (pełne opracowanie: Filipczak-Białkowska 2018).

Tabela 2. Uporządkowanie sądów ideologicznych zawartych w bazie ideologicznej partii Prawo i Sprawiedliwość według znaczników ideologicznych

\begin{tabular}{|c|c|c|}
\hline $\begin{array}{l}\text { Znacznik } \\
\text { ideolo- } \\
\text { giczny }\end{array}$ & Obszar ideologii & $\begin{array}{c}\text { Relewantne sądy ideologiczne } \\
\text { w bazie partii } \\
\text { Prawo i Sprawiedliwość }\end{array}$ \\
\hline \multicolumn{3}{|c|}{ konserwatyzm } \\
\hline 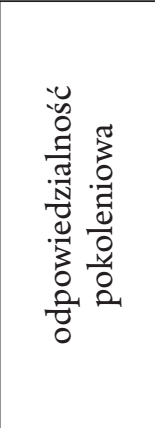 & $\begin{array}{l}\text { Obrona tradycji - wartości, } \\
\text { zwyczajów oraz instytucji. } \\
\text { Obecne pokolenie jest od- } \\
\text { powiedzialne za jakość życia } \\
\text { przyszłych pokoleń i osią- } \\
\text { gnięcia przodków. Zmiana, } \\
\text { gdy konieczna, wymaga } \\
\text { reform, bo one powstrzymują } \\
\text { falę rewolucji i podtrzymują } \\
\text { status quo. }\end{array}$ & $\begin{array}{l}\text { - tradycja } \\
\text { RO: Należy chronić tradycje regionalne } \\
\text { i narodowe. } \\
\text { RO: Należy zachować produkcję polskich } \\
\text { regionalnych produktów spożywczych } \\
\text { według tradycyjnych polskich receptur. } \\
\text { RO: Należy zachować produkcję oscypka, } \\
\text { bryndzy podhalańskiej, miodu wrzosowego } \\
\text { według tradycyjnych receptur. }\end{array}$ \\
\hline
\end{tabular}


Tabela 2 (cd.)

\begin{tabular}{|c|c|c|}
\hline $\begin{array}{c}\text { Znacznik } \\
\text { ideolo- } \\
\text { giczny }\end{array}$ & Obszar ideologii & $\begin{array}{c}\text { Relewantne sądy ideologiczne } \\
\text { w bazie partii } \\
\text { Prawo i Sprawiedliwość }\end{array}$ \\
\hline 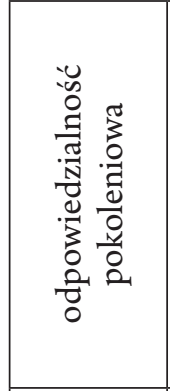 & & $\begin{array}{l}\text { - bezpieczna przyszłość } \\
\text { RO: Należy zabezpieczyć się przed proble- } \\
\text { mami mogącymi nastąpić w przyszłości. } \\
\text { - historia } \\
\text { RO: Obecne pokolenia decydują o tym, } \\
\text { jak będzie opisywana historia współcze- } \\
\text { snych czasów. } \\
\text { RO: Należy zadbać o to, aby historia stanu } \\
\text { wojennego nie była fałszowana. }\end{array}$ \\
\hline 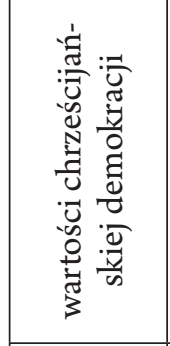 & $\begin{array}{l}\text { Prawo naturalne i kształt spo- } \\
\text { łeczeństwa pochodzi od Boga. } \\
\text { Jeśli istoty ludzkie ingerują } \\
\text { w sposób urządzenia świata, } \\
\text { to rzucają wyzwanie woli } \\
\text { Bożej, co może doprowadzić } \\
\text { do pogorszenia, a nie poprawy } \\
\text { stanu ludzkich spraw. }\end{array}$ & $\begin{array}{l}\text { RO: O trwaniu życia ludzkiego decyduje } \\
\text { Bóg. } \\
\text { RO: Zabijanie dziecka poczętego na życze- } \\
\text { nie kobiety to ingerencja w wolę Boga. } \\
\text { RO: Istota ludzka w stadium płodowym } \\
\text { to człowiek. } \\
\text { RO: Należy wyciągać wnioski z wydarzeń } \\
\text { opisywanych w Biblii. }\end{array}$ \\
\hline 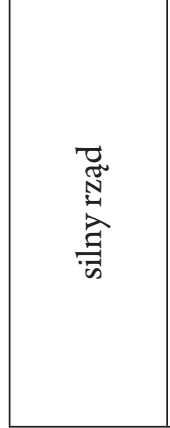 & $\begin{array}{l}\text { Centralizacja władzy, czyli } \\
\text { koncentracja uprawnień de- } \\
\text { cyzyjnych w rękach organów } \\
\text { centralnych i ograniczenie } \\
\text { kompetencji niższych szczebli } \\
\text { struktury organizacyjnej, } \\
\text { np. samorządu terytorialnego. }\end{array}$ & $\begin{array}{l}\text { - centralizacja władzy } \\
\text { RO: Należy umocnić struktury państwowe. } \\
\text { RO: Należy podnieść autorytet struktur } \\
\text { państwowych w oczach obywateli. } \\
\text { RO: Należy odbudować zaufanie Polaków } \\
\text { do państwa. } \\
\text { RO: Bez silnego i sprawnego państwa nie } \\
\text { będzie dostatniej Rzeczypospolitej. } \\
\text { RO: Nie należy wprowadzać rozwiązań } \\
\text { prawnych, które osłabiają państwo. }\end{array}$ \\
\hline 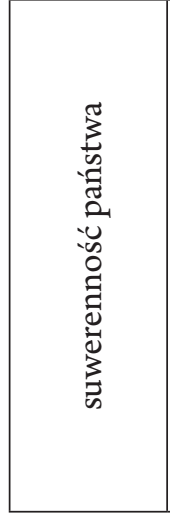 & $\begin{array}{l}\text { Podkreślanie konieczności } \\
\text { zachowania suwerenności } \\
\text { narodowej i kulturowej } \\
\text { w ramach Europy. Potrzeba } \\
\text { obrony suwerennych insty- } \\
\text { tucji narodowych i odrębnej } \\
\text { waluty narodowej jako sym- } \\
\text { boli tożsamości narodowej. } \\
\text { Epokowym sukcesem jest } \\
\text { zwycięstwo nad komuni- } \\
\text { zmem. }\end{array}$ & $\begin{array}{l}\text { - ograniczenie wplywu Unii Europejskiej } \\
\text { na polskie prawo } \\
\text { RO: Należy zapewnić polskim obywa- } \\
\text { telom przestrzeganie ich praw w Unii } \\
\text { Europejskiej. } \\
\text { RO: Należy jasno określić zasady, kiedy } \\
\text { obywatel polski lub obywatel obcego pań- } \\
\text { stwa nie będzie mógł być wydany na mocy } \\
\text { europejskiego nakazu aresztowania. } \\
\text { RO: Prawodawstwo Unii Europejskiej jest } \\
\text { przeciwne barierom moralnym ogranicza- } \\
\text { jącym jednostki. }\end{array}$ \\
\hline
\end{tabular}




\begin{tabular}{|c|c|c|}
\hline $\begin{array}{c}\text { Znacznik } \\
\text { ideolo- } \\
\text { giczny }\end{array}$ & Obszar ideologii & $\begin{array}{c}\text { Relewantne sądy ideologiczne } \\
\text { w bazie partii } \\
\text { Prawo i Sprawiedliwość } \\
\end{array}$ \\
\hline 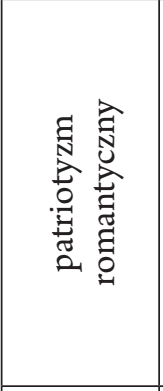 & $\begin{array}{l}\text { Naród jest mobilizowany do } \\
\text { walki za „ojczyznę”, wspieranie } \\
\text { „dumy z własnego narodu”. } \\
\text { Należy upamiętniać minione } \\
\text { epoki chwały czy triumfu } \\
\text { narodu przez wspominanie } \\
\text { zwycięstw zbrojnych, wyko- } \\
\text { rzystywanie symboli tożsamo- } \\
\text { ści narodowej. }\end{array}$ & $\begin{array}{l}\text { RO: Ruchy patriotyczne narodu należy } \\
\text { uhonorować. } \\
\text { RO: Wydarzenia, które były szkołą patrio- } \\
\text { tyzmu dla obywateli, były dobre. } \\
\text { RO: Ten, kto przejawia silną miłość do } \\
\text { ojczyzny, zasługuje na szacunek. }\end{array}$ \\
\hline 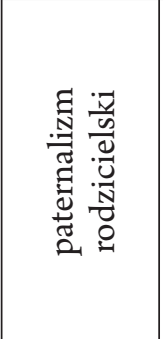 & $\begin{array}{l}\text { Rodzice mają władzę nad } \\
\text { dziećmi: kontrolują praktycz- } \\
\text { nie każdy aspekt ich młodego } \\
\text { życia; dzieci nie wiedzą, co } \\
\text { jest dla nich dobre. Rodzice są } \\
\text { zobowiązani do zapewnienia } \\
\text { warunków bytowych, gdy } \\
\text { trzeba, także do karania dzieci. }\end{array}$ & $\begin{array}{l}\text { RO: Rodzice decydują, co jest dobre dla } \\
\text { dziecka, dopóki nie uzyska ono pełnolet- } \\
\text { niości. } \\
\text { RO: Umożliwienie podejmowania decyzji } \\
\text { o aborcji nieletnim to niekorzystna zmiana. }\end{array}$ \\
\hline
\end{tabular}

Źródło: opracowanie własne.

W wyniku tej części analizy opracowałam ilościowy rozkład odniesień do poszczególnych ideologii w wypowiedziach posłów partii Prawo i Sprawiedliwość. Wyniki prezentuje tabela 3, a procentowy udział ideologii w bazie sądów ideologicznych partii wykres 1.

Tabela 3. Ilościowy rozkład odniesień do poszczególnych ideologii w wypowiedziach posłów partii Prawo i Sprawiedliwość

\begin{tabular}{|l|c|}
\hline \multicolumn{1}{|c|}{ Ideologia } & Liczba odniesień \\
\hline konserwatyzm & 99 \\
\hline socjalizm & 64 \\
\hline liberalizm & 44 \\
\hline ogółem & 207 \\
\hline
\end{tabular}

Źródło: opracowanie własne.

W obrębie każdej ideologii można było wskazać znaczniki, które charakteryzowały się najwyższą liczbą odniesień. Pozwoliło to określić dominujący obszar ideologiczny w dyskursie danej partii. 
Dla przykładu odniesienia do znaczników konserwatyzmu w bazie ideologicznej partii Prawo i Sprawiedliwość przedstawiam w tabeli 4.

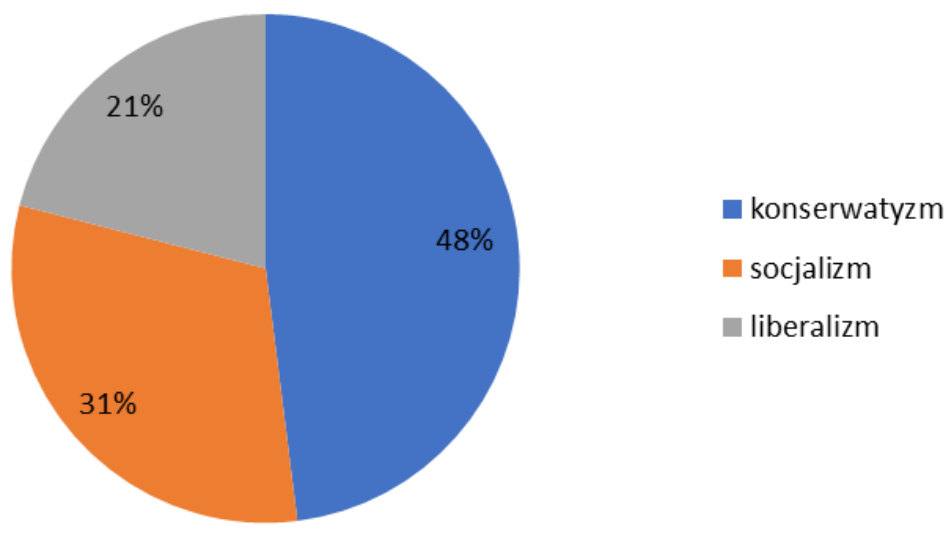

Wykres 1. Procentowy udział ideologii w bazie sądów ideologicznych Prawa i Sprawiedliwości

Źródło: opracowanie własne.

Tabela 4. Odniesienia do znaczników ideologicznych konserwatyzmu w bazie ideologicznej partii Prawo i Sprawiedliwość

\begin{tabular}{|l|c|}
\hline \multicolumn{1}{|c|}{ Znacznik ideologiczny } & Liczba odniesień \\
\hline silny rząd & 40 \\
\hline paternalizm państwa & 24 \\
\hline suwerenność państwa & 13 \\
\hline odpowiedzialność pokoleniowa & 11 \\
\hline wartości chrześcijańskiej demokracji & 4 \\
\hline autorytaryzm rządów & 3 \\
\hline patriotyzm romantyczny & 3 \\
\hline paternalizm rodzicielski & 1 \\
\hline
\end{tabular}

Źródło: opracowanie własne.

Uzyskane dane stały się podstawą do skonstruowania profilu ideologicznego partii, który stanowi wyraz jej orientacji ideologicznej w okresie objętym badaniem, tj. w latach 2005-2006. Profil ideologiczny Prawa i Sprawiedliwości przedstawiono w tabeli 5 (w opracowaniu odrzucono znaczniki mające poniżej 5 rekordów). 
Tabela 5. Profil ideologiczny partii Prawo i Sprawiedliwość

\begin{tabular}{|l|l|c|}
\hline \multirow{4}{*}{ konserwatyzm } & \multicolumn{1}{|c|}{ Znacznik ideologiczny } & Liczba odniesień \\
\cline { 2 - 3 } & silny rząd & 40 \\
\cline { 2 - 3 } & paternalizm państwa & 24 \\
\cline { 2 - 3 } & suwerenność państwa & 13 \\
\cline { 2 - 3 } & odpowiedzialność pokoleniowa & 11 \\
\hline \multirow{3}{*}{ socjalizeralizm } & społeczna odpowiedzialność władzy & 21 \\
\cline { 2 - 3 } & wolności obywatelskie & 6 \\
\cline { 2 - 3 } & państwo opiekuńcze & 21 \\
\cline { 2 - 3 } & protekcjonizm gospodarczy & 10 \\
\cline { 2 - 3 } & ograniczenie skutków bezrobocia & 7 \\
\cline { 2 - 3 } & solidaryzm społeczny & 6 \\
\cline { 2 - 3 } & prawa pracownicze & 6 \\
\cline { 2 - 3 } & interwencjonizm gospodarczy & 9 \\
\hline
\end{tabular}

Źródło: opracowanie własne.

W orientacji ideologicznej Prawa i Sprawiedliwości wyraźnie zaznaczyła się dominacja pewnych obszarów ideologicznych wyrażonych znacznikami. Należy zwrócić uwagę na kluczową rolę ideologii konserwatywnej w dyskursie partii, pochodzą z niej znaczniki: „silny rząd”, „paternalizm państwa” oraz „suwerenność państwa”. Wysoki wynik dla znacznika „społeczna odpowiedzialność władzy”, który jest właściwy dla liberalizmu, był efektem tendencji do rozliczania poprzedników (rządu Sojuszu Lewicy Demokratycznej) z ich decyzji politycznych. Powyższe zestawienie uwypukliło też istotność znacznika „państwo opiekuńcze”, będącego częścią ideologii socjalizmu.

W analogiczny sposób przeprowadziłam analizę dla pozostałych badanych podmiotów politycznych, tj. dla partii Platforma Obywatelska, Sojusz Lewicy Demokratycznej, Samoobrona Rzeczypospolitej Polskiej, Liga Polskich Rodzin oraz Polskie Stronnictwo Ludowe (więcej można przeczytać w: Filipczak-Białkowska 2018: 163-196).

\subsubsection{Specyfika polskiego dyskursu parlamentarnego w latach 2005-2006}

Na podstawie danych pochodzących ze skonstruowanych profili ideologicznych dla podmiotów funkcjonujących w parlamencie w badanym okresie przygotowałam zestawienie całościowe, uwzględniające wszystkie badane podmioty, jak w tabeli 6. 
Tabela 6. Reprezentacja znaczników ideologicznych w dominujących obszarach ideologicznych partii - zestawienie całościowe

\begin{tabular}{|c|c|c|c|c|c|c|c|}
\hline & Znacznik ideologiczny & PiS & PO & SRP & SLD & LPR & PSL \\
\hline \multirow[t]{5}{*}{ konserwatyzm } & wartości chrześcijańskiej demokracji & & & $\mathrm{V}$ & & $\mathrm{V}$ & \\
\hline & silny rząd & $\mathrm{V}$ & & & & & \\
\hline & paternalizm państwa & $\mathrm{V}$ & & $\mathrm{V}$ & & $\mathrm{V}$ & \\
\hline & autorytaryzm rządów & & & & & $\mathrm{V}$ & \\
\hline & suwerenność państwa & $\mathrm{V}$ & & & & $\mathrm{V}$ & \\
\hline \multirow[t]{8}{*}{ liberalizm } & społeczna odpowiedzialność władzy & $\mathrm{V}$ & & $\mathrm{V}$ & & $\mathrm{V}$ & \\
\hline & granice sprawowania władzy & & $\mathrm{V}$ & & $\mathrm{V}$ & $\mathrm{V}$ & $\mathrm{V}$ \\
\hline & wolności obywatelskie & & & $\mathrm{V}$ & $\mathrm{V}$ & & $\mathrm{V}$ \\
\hline & państwo usługodawca & & $\mathrm{V}$ & & & & \\
\hline & wolność absolutna jednostek & & & & $\mathrm{V}$ & & \\
\hline & samorządność & & $\mathrm{V}$ & & $\mathrm{V}$ & & $\mathrm{V}$ \\
\hline & integracja europejska & & $\mathrm{V}$ & & & & \\
\hline & inwestycje gospodarcze & & $\mathrm{V}$ & & $\mathrm{V}$ & & \\
\hline \multirow[t]{6}{*}{ socjalizm } & protekcjonizm gospodarczy & & & $\mathrm{V}$ & & & \\
\hline & państwo opiekuńcze & $\mathrm{V}$ & & & & & \\
\hline & związki zawodowe & & & & & & $\mathrm{V}$ \\
\hline & prawa pracownicze & & & & & & \\
\hline & nacjonalizacja gospodarki & & & & & & $\mathrm{V}$ \\
\hline & ograniczenie skutków bezrobocia & & & $\mathrm{V}$ & & & \\
\hline
\end{tabular}

Źródło: opracowanie własne.

Obserwacja uzyskanych danych pozwoliła wnioskować o możliwych przestrzeniach współpracy między poszczególnymi klubami parlamentarnymi. W zakresie takich znaczników, jak: „wolności obywatelskie”, „państwo usługodawca”, „społeczna odpowiedzialność władzy”, „granice sprawowania władzy”, „prawa pracownicze”, a także „solidaryzm społeczny” i „protekcjonizm gospodarczy”, pojawily się odniesienia w bazie ideologicznej niemal wszystkich klubów parlamentarnych. Co ciekawe, znaczniki te pochodziły w większości z ideologii liberalnej. W literaturze przedmiotu pojawiały się założenia, iż sfera ówczesnej polityki europejskiej zdominowana była przez ideologię liberalną - uzyskane wyniki zdawały się potwierdzać tę tezę. Liczne odwołania do ideologii socjalizmu można zaś tłumaczyć sytuacją społeczno-gospodarczą Polski, która w badanym okresie nadal określana była jako kraj rozwijający się o kształtującej się dopiero przestrzeni wolnego rynku. 
Partie koalicji rządzącej, czyli Prawo i Sprawiedliwość - Samoobrona RP - Liga Polskich Rodzin, płaszczyznę porozumienia znalazły w obszarze wyrażonym znacznikiem "paternalizm państwa” - ten sposób sprawowania rządów był bliski każdej z tych grup. Podobnie silna tendencja do egzekwowania odpowiedzialności za podejmowane decyzje i płynących z niej konsekwencji kierowana do poprzedników politycznych stworzyła przestrzeń współpracy w ramach znacznika „społeczna odpowiedzialność władzy”.Jednak już dla dążenia do utworzenia silnego rządu Prawo i Sprawiedliwość nie znalazło oddanego sojusznika, a nawet wręcz przeciwnie - ukonstytuowała się silna opozycja wokół obszaru ideologicznego, określonego znacznikiem „granice sprawowania władzy”. Podobnie istotne dla Ligi Polskich Rodzin kwestie wyrażone znacznikiem ideologicznym „wartości chrześcijańskiej demokracji”, oscylujące na krawędzi fundamentalizmu religijnego, nie stanowily centrum zainteresowania innych klubów parlamentarnych. W jednej z debat kwestia ta podniesiona została przez reprezentanta LPR: „Cieszy mnie, że jest to nasza wspólna inicjatywa ponadklubowa. Ale niepokoi mnie i boli, że wielu parlamentarzystów Prawa i Sprawiedliwości, występując w niektórych mediach, prezentuje zupełnie inne stanowisko". Na płaszczyźnie gospodarczej Platforma Obywatelska przejawiała nastawienie podobne do stanowiska Sojuszu Lewicy Demokratycznej w zakresie znacznika ideologicznego „inwestycje gospodarcze”, w obrębie znacznika „samorządność” panowała zgodność między tymi klubami: PiS, SLD i PSL.

W tym miejscu warto rozważyć pewną wątpliwość: czy uzyskane wyniki mogą być zdeterminowane tematyką debat, które zostały wybrane do analizy? $\mathrm{W}$ przedstawionym opracowaniu uznaje się, że mechanizm działania ideologii pozbawiony jest jakichkolwiek aspektów treściowych, „tym samym ideologia odnosić się może do wszystkich tematów komunikacji i do wszystkich sytuacji komunikacyjnych, niezależnie od czasu i przestrzeni komunikacji” (Fleischer 2008: 97). Z tego założenia wynika, iż bez względu na poruszany w debacie temat (organizacja służby zdrowia, obronność kraju czy wprowadzenie obowiązku noszenia kamizelek odblaskowych przez pieszych) treści ideologiczne preferowane przez daną partię i tak się ujawnią. Niewątpliwie jednak dla rzetelności badań ważne jest uświadomienie sobie przez badacza, że powyższe stwierdzenie przyjęte jest z mocą założenia i zachowanie pewnej ostrożności przy formułowaniu ostatecznych wniosków.

W ramach uzupełnienia i argumentu potwierdzającego prawdziwość założonych w pracy tez warto dodać, że po wyborach w 2007 roku powstała koalicja PO-PSL. W tabeli 6 zaznacza się wspólny obszar ideologiczny tych ugrupowań wyrażony znacznikiem „samorządność”. W „Deklaracji koalicyjnej” podpisanej przez przewodniczących partii 23 listopada 2007 roku zapisano m.in.: „Obie strony deklarują wolę dalszej przebudowy ustrojowej państwa w stronę jego większej decentralizacji poprzez zwiększenie roli samorządów, poszerzenie ich kompetencji i wzmocnienie finansowych podstaw działania oraz szerokiego stosowania 
zasady pomocniczości”. W okresie 2005-2006 tylko Platforma Obywatelska przejawiała pozytywną postawę względem nawiązania bliskiej współpracy z Unią Europejską, inne kluby bądź nie uwzględniały tego obiektu w swoim dyskursie, bądź odnosiły się do niego z wrogością (np. Samoobrona RP, LPR).

Na koniec należy omówić, jak uzyskane dane wpłynęły na weryfikację zaproponowanych hipotez badawczych, które brzmiały:

H1: Wypowiedzi reprezentantów partii politycznych wskazują na pluralistyczny charakter polskiego systemu partyjnego.

H2: Profil ideologiczny partii zbudowany jest z komponentów różnych prototypowych systemów ideologicznych.

H3: W orientacji ideologicznej partii można wyznaczyć dominujący obszar ideologiczny, czyli pewne aspekty ideologiczne będą szczególnie silnie reprezentowane.

Należy stwierdzić, że wyznaczone hipotezy znajdują potwierdzenie w uzyskanych danych. Analiza debat parlamentarnych przeprowadzona została metodą wywodzącą się z gramatyki komunikacyjnej. Profile ideologiczne partii politycznych, będące wyrazem ich orientacji ideologicznej, zbudowane są z komponentów różnych prototypowych systemów ideologicznych, przy czym należy zaznaczyć, że jest to najczęściej spotykana sytuacja, ale nie konieczna - możliwe jest, że profil partii ideologicznej będzie zbudowany wyłącznie z komponentów jednej ideologii, taka sytuacja utrudnia jednak nawiązanie współpracy politycznej np. w momencie tworzenia rządu koalicyjnego. Pomimo powszechnego swoistego eklektyzmu ideologicznego w profilach badanych partii, możliwe było wskazanie dominujących w ich orientacji ideologicznej obszarów ideologicznych. Opierając się na przeprowadzonym badaniu, można stwierdzić, że szacowane na podstawie wypowiedzi reprezentantów partii politycznych zróżnicowanie ideologiczne polskiego systemu partyjnego w latach 2005-2006 zostało potwierdzone. Metoda badania dyskursu parlamentarnego oparta na założeniach gramatyki komunikacyjnej i wykorzystująca koncepcję znaczników ideologicznych jest adekwatna do realizacji wyznaczonych celów badawczych.

\section{Literatura}

Awdiejew Aleksy (2008), Ideologia. Postawa i komunikacja, [w: ] Ideologie w stowach i obrazach, red. I. Kamińska-Szmaj i in., Wydawnictwo Uniwersytetu Wrocławskiego, Wrocław, s. 65-72.

Awdiejew Aleksy, Habrajska Grażyna (2009), Strategie propagandowe i agitacyjne, [w:] Rozmowy o komunikacji 3. Problemy komunikacji społecznej, red. G. Habrajska, Oficyna Wydawnicza Leksem, Łask, s. 9-54.

Charciarek Andrzej (2015), Zwroty etykietalne jako chwyt retoryczny w polskim i czeskim dyskursie parlamentarnym, [w:] Oblicza przeciwnika: język a rzeczywistość $w$ kategoriach ekspresji, polityki, ideologii, red. P. Czerwiński, Wydawnictwo Uniwersytetu Śląskiego, Katowice, s. 15-40. 
Figiel Agnieszka (2009), Języki IV RP. Podziały społeczno-polityczne w dyskursie polityki, Wydawnictwo Naukowe Wydziału Nauk Społecznych Uniwersytetu im. A. Mickiewicza w Poznaniu, Poznań.

Filipczak Anita (2010), Mechanizmy manifestowania orientacji aksjologicznej na przykładzie debat parlamentarnych, [w:] Rozmowy o komunikacji 4. Metodologia i praktyka komunikacji społecznej, red. G. Habrajska, Oficyna Wydawnicza Leksem, Łask, s. 71-86.

Filipczak-Białkowska Anita (2018), Mechanizmy manifestowania orientacji ideologicznej $w$ dyskursie politycznym, Wydawnictwo Uniwersytetu Łódzkiego - Primum Verbum, Łódź.

Grzegorzewski Krzysztof (2014), Homo rethoricus $w$ telewizyjnym dziennikarstwie politycznym, Wydawnictwo Uniwersytetu Łódzkiego, Łódź.

Kamińska-Szmaj Irena (2001), Słowa na wolności. Język polityki po 1989: wypowiedzi, dowcip polityczny, stownik inwektyw, Wydawnictwo Europa, Wrocław.

Kampka Agnieszka (2009), Perswazja w języku polityki, Wydawnictwo Naukowe Scholar, Warszawa.

Laskowska Elżbieta (2004), Dyskurs parlamentarny w ujęciu komunikacyjnym, Wydawnictwo Akademii Bydgoskiej im. Kazimierza Wielkiego, Bydgoszcz.

Loewe Iwona (2018), Dyskurs telewizyjny w świetle lingwistyki mediów, Wydawnictwo Uniwersytetu Śląskiego, Katowice.

Michalewski Kazimierz (2013), Telewizyjny dyskurs polityczny, [w: Jazyk a diskurz v kulturnom a politickom kontexte, red. S. Ondrejovič, Veda, Vydavatel'stvo Slovenskej Akadémie Vied, Bratislava, s. 77-84.

Pałuszyńska Edyta (2012), Strategie dziennikarzy i ich rozmówców w medialnym dyskursie publicznym, Wydawnictwo Uniwersytetu Łódzkiego, Łódź.

Piekot Tomasz, Poprawa Marcin (2009), Trzy niebezpieczeństwa badań nad ideologiami, [w: Ideologie codzienności, red. I. Kamińska-Szmaj i in., Wydawnictwo Uniwersytetu Wrocławskiego, Wrocław, s. 7-10.

Polkowska Laura (2015), Język prawicy, Wydawnictwo Uniwersytetu Kardynała Stefana Wyszyńskiego w Warszawie, Warszawa.

Pstrąg Jakub (2004), Werbalne i niewerbalne techniki i strategie konwersacyjnego oponowania na materiale debat telewizyjnych, Universitas, Kraków.

Rasiński Lothar (2009), "Reguty” i "gry” świata społecznego - Wittgenstein, de Saussure i zwrot lingwistyczny w filozofii społecznej, [w:] Jezzyk, dyskurs, społeczeństwo. Zwrot lingwistyczny $w$ filozofii współczesnej, red. L. Rasiński, Wydawnictwo Naukowe PWN, Warszawa, s. 7-27.

Sieradzka-Baziur Bożena (2011), Język polityki - dotychczasowe prace oraz perspektywy badawcze, „Horyzonty Polityki”, nr 2, s. 89-110.

Siewierska-Chmaj Anna (2004), Język polskiej polityki: politologiczno-semantyczna analiza exposé premierów Polski w latach 1919-2004, Wyższa Szkoła Informatyki i Zarządzania, Rzeszów.

Szkudlarek-Śmiechowicz Ewa (2010), Tekst $w$ radiowej i telewizyjnej debacie politycznej. Struktura - spójność - funkcjonalność, Wydawnictwo Uniwersytetu Łódzkiego, Łódź.

Śpiewak Paweł (2004), Obietnice demokracji, Prószyński i S-ka, Warszawa. 
Wasilewski Jacek (2014), Debata a media, [w:] Sztuka debaty, red. M. Kochan, Instytut Kultury Miejskiej, Gdańsk, s. 109-126.

Wasilewski Jacek, Skibiński Adam (2008), Prowadzeni stowami. Retoryka motywacji w komunikacji publicznej, Difin, Warszawa.

Wodak Ruth (2011), Wstęp, [w:] Jakościowa analiza dyskursu w naukach spotecznych, red. R. Wodak, M. Krzyżanowski, Oficyna Wydawnicza Łośgraf, Warszawa, s. 11-48. 